\title{
De Onde Vem o Bem-Estar Financeiro?: Análise dos Fatores Comportamentais, do Gerenciamento Financeiro e da Renda
}

\author{
Kelmara Mendes Vieira \\ Universidade Federal de Santa Maria - Brasil \\ kelmara@terra.com.br \\ Luana dos Santos Fraga \\ Universidade Federal de Santa Maria - Brasil \\ luana.fraga92@gmail.com \\ Vanessa Martins Valcanover \\ Universidade Federal de Santa Maria - Brasil \\ son.vanessa@hotmail.com \\ Verônica Dalmolin Cattelan \\ Universidade Federal de Santa Maria - Brasil \\ veronica_vdc@hotmail.com \\ Silvia Amélia Mendonça Flores \\ Universidade Federal do Pampa (RS) - Brasil \\ silviaamflores@gmail.com \\ Jéssica Pulino Campara \\ Universidade Federal de Santa Catarina - Brasil \\ jecampara@hotmail.com
}

\section{Resumo}

Em um cenário de crise econômica, a preocupação com as finanças e manutenção do bemestar financeiro tornam-se eminentes. Logo, evidenciar os fatores que possam colaborar no aumento do nível de bem-estar financeiro é importante para que os indivíduos busquem as melhores alternativas para administrar os recursos e atentem-se para os fatores que podem influenciá-lo. Assim, o objetivo principal do presente estudo foi analisar a influência dos fatores comportamentais alfabetização financeira, atitude ao endividamento, gerenciamento financeiro e renda no bem-estar financeiro dos indivíduos. Foram aplicados 1577 questionários no Rio Grande do Sul e para análise dos dados utilizou-se estatística descritiva, análise fatorial confirmatória e análise de regressão linear múltipla. Os resultados vão ao encontro do que se discute em relação ao conceito de bem-estar financeiro, ou seja, 
pessoas que tem controle de suas ações em âmbito financeiro, que evitam preocupações relativas a pagamentos de dívidas, tendem a maior bem-estar financeiro. Pode-se atribuir esse controle ao comportamento financeiro, o qual representa uma dimensão mais concreta da alfabetização financeira.

Palavras-chave: bem-estar financeiro, alfabetização financeira, atitude ao endividamento, gerenciamento financeiro 


\title{
Where does the Financial Well-being come from?: An Analysis of Behavioural Factors, Financial Management and Income
}

\author{
Kelmara Mendes Vieira \\ Universidade Federal de Santa Maria - Brasil \\ kelmara@terra.com.br \\ Luana dos Santos Fraga \\ Universidade Federal de Santa Maria - Brasil \\ luana.fraga92@gmail.com \\ Vanessa Martins Valcanover \\ Universidade Federal de Santa Maria - Brasil \\ son.vanessa@hotmail.com \\ Verônica Dalmolin Cattelan \\ Universidade Federal de Santa Maria - Brasil \\ veronica_vdc@hotmail.com \\ Silvia Amélia Mendonça Flores \\ Universidade Federal do Pampa (RS) - Brasil \\ silviaamflores@gmail.com \\ Jéssica Pulino Campara \\ Universidade Federal de Santa Catarina - Brasil \\ jecampara@hotmail.com
}

\begin{abstract}
In a scenario of economic crisis, the concern with finances and maintenance of the financial well-being become eminent. Then, highlight the factors that can assist the increase of financial well-being level is important for individuals to seek the best alternatives to manage resources and to notice the factors that can influence it. Thus, this research aims to analyze the influence of behavioral factors (financial literacy and attitude towards indebtedness), financial management and income on the financial well-being of individuals. It was used the multivariate linear regression to estimate this influence. The results meet what is discussed in relation to the concept of financial well-being, that is, individuals who have control of their actions in the financial area, avoiding concerns related to debt payments, tend to have
\end{abstract}


greater financial well-being. It is possible to assign this control to the financial behavior, which represents a more concrete dimension of financial literacy.

Keywords: financial well-being, financial literacy, attitude towards indebtedness, financial management 
Em um cenário de crise econômica, com queda do PIB, desaceleração da indústria nacional, aumento do desemprego, inflação alta e queda no poder de compra, a preocupação com o gerenciamento financeiro, entendido como o processo de ajuste entre os recursos que as famílias têm disponível e suas demandas (Chen et al., 2012), torna-se eminente. Além disso, os indivíduos necessitam empenhar-se com mais afinco na busca pelo bem-estar financeiro (BEF), conceituado como situação em que são cumpridas totalmente as obrigações financeiras pessoais (CFPB, 2015). Assim, evidenciar os fatores que possam colaborar no aumento do nível de BEF da população, torna-se útil, no sentido de que os indivíduos busquem as melhores alternativas para administrar os recursos e atentem-se para os fatores que apresentem maior influência sobre as suas finanças e o consequente bem-estar financeiro.

Alguns desses fatores são de cunho comportamental, como a alfabetização financeira, a qual representa combinação de consciência, conhecimento, habilidade, atitude e comportamento necessários para tomar decisões financeiras sólidas (OECD, 2015) e a atitude ao endividamento, que pode ser entendida como a situação em que os indivíduos são mais predispostos à contração de obrigações financeiras sem condições de pagamento (Moura, 2005). Todavia, o gerenciamento financeiro (Plagnol, 2011; Xiao et al., 2006; Shim et al., 2009) e a renda (Gutter \& Copur, 2011; Diniz et al., 2014) também são identificados como influentes no BEF.

Tratando-se de cada fator, a OECD (2015) relata que alfabetização financeira é condição prévia para que sejam feitas decisões que melhoram o bem-estar financeiro dos indivíduos. Norvilitis et al. (2003) afirmam que altos níveis de dívida se relacionam com menor confiança na capacidade de gerenciar o dinheiro, o que gera maior preocupação com os compromissos financeiros e menor sensação de bem-estar financeiro. Plagnol (2011) salienta que gerir recursos disponíveis de forma consciente, equilibrando receitas e despesas, controlando os gastos e poupando é importante para manutenção de uma boa situação financeira. Tem-se também, que diferentes níveis de renda podem levar a diferentes níveis de bem-estar financeiro, sendo que quanto maior a renda, maior o bem-estar (Sumarwan, 1990; Delafrooz \& Paim, 2011).

Diante dessas relações, o objetivo consiste em analisar a influência da alfabetização financeira, atitude ao endividamento, gerenciamento financeiro e renda no bem-estar financeiro dos indivíduos. Como objetivos específicos: i) analisar o nível de alfabetização 
financeira, atitude ao endividamento, características do gerenciamento financeiro e bemestar financeiro dos entrevistados e ii) validar os construtos comportamentais investigados.

Contextualizando os aspectos importantes do estudo, aponta-se que na última década, o cenário socioeconômico brasileiro passou por transformações, em que muito indivíduos vivenciaram uma mobilidade social, alcançando maiores níveis de renda e acesso ao crédito. Essa situação é considerada um aspecto importante para o bem-estar econômico, pois impulsiona os níveis de consumo. Todavia, um possível problema resultante do aumento do crédito é que no momento que a capacidade de consumo cresce mais do que a renda pessoal e familiar, pode ocasionar superendividamento (Porto, 2012).

Salienta-se ainda que situação financeira atual do país, está atrelada a perspectivas negativas e a dificuldade para gerenciar os recursos acaba por elevar os percentuais de endividamento e inadimplência, que em abril de 2016 totalizaram 59,6\% (percentual de endividados), 23,2\% (com contas em atraso) e 8,2\% (não terão condições de pagar) (CNC, 2016). Assim, a importância do trabalho para o campo da administração está atrelada ao fato de que maiores níveis de endividamento e a consequente redução do bem-estar financeiro, podem levar a uma redução da atividade econômica e do poder de compra, o que impacta no mercado financeiro, no gerenciamento de risco de crédito e nos níveis de investimento e financiamento das empresas.

Como inovação destaca-se a falta de pesquisas científicas que avaliem o impacto concomitante de diferentes fatores comportamentais no bem-estar financeiro em diferentes níveis de renda. Atenta-se ainda para o questionário aplicado, que inclui adaptação de instrumentos de diversos autores e instituições reconhecidas internacionalmente, além da utilização de questões de diferentes perspectivas financeiras, como gerenciamento, atitude, comportamento e conhecimento, podendo assim relacioná-las.

\section{Referencial Teórico}

O processo de tomada de decisão envolve diversos aspectos que relacionados entre si vão conduzir a decisão final. No processo decisório financeiro e na avaliação do risco, temse a Teoria da Utilidade Esperada (TUE), a qual prevê uma avaliação racional do risco. Porém, quando trata-se de um ambiente de incerteza, onde a decisão racional pode ser difícil de alcançar, a TUE não se aplica. Com isso, surge as Finanças Comportamentais, que estruturam a Teoria do Prospecto, uma alternativa para as imperfeições da Teoria da 
Utilidade Esperada (Moreira, 2012). A Teoria do Prospecto, desenvolvida por Kahneman \& Tversky (1979) procura explicar o comportamento de tomada de decisão do investidor levando em consideração as decisões emocionais e automáticas, além das racionais e deliberadas (Kahneman, 2003).

Costa Jr., Macedo Jr, Zindel, \& Arruda (2007) expõem que as finanças comportamentais consideram a tomada de decisão no mercado financeiro, entendendo os indivíduos como seres humanos e consequentemente sujeitos a vieses comportamentais. A psicologia cognitiva moderna demonstrou que muitas de nossas decisões cotidianas são automáticas e podem ser influenciadas pelas emoções, ou seja, não pensamos antes de decidir (Macedo Jr; Kolinsky, \& De Morais, 2011).

Tendo em vista que as finanças comportamentais consideram aspectos subjetivos, pode-se relacionar essa teoria ao bem-estar financeiro, o qual também pressupõe avaliação de características pessoais e subjetividade. Destaca-se ainda que investidores desinformados ou inexperientes podem cometer mais erros cognitivos do que aqueles informados e experientes (Shefrin \& Statman, 1994). Assim, indivíduos com maior conhecimento e melhores comportamentos e atitudes financeiras, tendem a tomar decisões mais acertadas e que contribuam para uma maior satisfação com as finanças.

\section{Bem-estar financeiro: definição e escalas}

O bem-estar financeiro é o estado no qual o indivíduo consegue cumprir totalmente suas obrigações financeiras, sentindo-se seguro e apto a realizar escolhas que permitam aproveitar a vida (CFPB, 2015). Ainda, como a satisfação com aspectos materiais e nãomateriais relacionados à situação financeira pessoal, percepção subjetiva dos recursos financeiros e estabilidade (Delafrooz \& Paim, 2011). Shim et al. (2009) o compreendem como consequência do nível de endividamento e satisfação com a situação financeira.

Quanto às formas de mensuração, em meados do ano de 1990, ainda eram considerados apenas aspectos objetivos, relacionados à renda familiar, como itens materiais (alimentação, vestuário, habitação), recursos financeiros disponíveis para atender emergências, patrimônio líquido e nível de poupança (Sumarwan; 1990; Lown \& Ju, 1992). Contudo, evidenciou-se que aspectos subjetivos, relacionados com as características pessoais de cada um também influenciam no bem-estar financeiro. Assim, passou-se a utilizar escalas com indicadores subjetivos. Dentre as mais proeminentes, cita-se Norvilitis 
et al. (2003); Prawitz et al. (2006), denominada Pessoal Financial Wellness Scale, e a desenvolvida pelo Consumer Financial Protection Bureau (CFPB, 2015).

Levando em consideração as formas de mensuração objetivas e subjetivas, torna-se importante verificar sua influência no bem-estar financeiro, visto que características do indivíduo e do ambiente podem impactar positivamente e/ou negativamente. Assim, Shim et al. (2009) afirmam que a facilidade na execução de compras, notadamente pela internet; bem como pela disponibilidade de crédito e meios acessíveis para empréstimos, e o acesso aos cartões de crédito são consideradas ameaças. Porém, salienta-se que nem sempre essas facilidades são ruins, uma vez que podem ser consideradas estratégias financeiras num contexto de crescimento econômico (Marques et al., 2000). Observa-se ainda, que em um cenário com inflação crescente e diminuição do poder aquisitivo, o acesso ao crédito pode ser fundamental para o atendimento imediato de necessidades (Castro, 2014).

Ainda, estudos vêm apresentando que fatores comportamentais, como a alfabetização financeira, atitude ao endividamento, além da maneira como os indivíduos gerenciam seus recursos e seu nível de renda também podem influenciar no bem-estar financeiro (OECD, 2013a; Lown \& Ju, 1992; Xiao et al., 2006; Gutter \& Copur, 2011; Delafrooz \& Paim, 2011; Sumarwan, 1990).

\section{Determinantes do bem-estar financeiro}

Incita-se a alfabetização financeira, em três dimensões interligadas: o conhecimento financeiro, a atitude financeira e o comportamento financeiro, como fator comportamental determinante do BEF (OECD, 2013a). A primeira envolve compreender e aprofundar conceitos. A segunda é reconhecida como combinação de conceitos, informações e emoções sobre a aprendizagem (Shockey, 2002). Porém, é através do comportamento financeiro (terceira dimensão) que se concretiza o equilíbrio ou desequilíbrio das finanças.

Quanto às suas formas de mensuração, não existe um consenso sobre a melhor, porém existem algumas mais utilizadas, como: Financial Literacy Survey, promovida pela National Foundation for Credit Counseling (NFCC) e pela The Network Branded Prepaid Card Association (NBPCA), a qual mensura atitudes e comportamentos dos indivíduos (NFCC, 2013); a National Financial Capability Study (NFCS), que estabelece uma medida de referência da capacidade financeira de adultos americanos (NFCS, 2012); a Organization for Economic Co-operation and Development (OECD), que avalia o nível de conhecimento 
financeiro, o comportamento financeiro e a atitude financeira e a de O’Neill \& Xiao (2012), que descreve a frequência de realização de práticas recomendadas para uma gestão financeira eficaz em três aspectos: orçamento, gasto e poupança.

Salienta-se que mensurar e difundir a alfabetização financeira é de grande importância, pois aumentar o conhecimento financeiro e melhorar atitudes, são condições prévias para decisões financeiras mais acertadas e melhor bem-estar financeiro dos indivíduos (OECD, 2015). Salienta-se ainda a relação do bem-estar financeiro com as dimensões supracitadas da alfabetização financeira, como atitude e comportamento. Existe efeito direto das boas atitudes financeiras em relação ao bem-estar financeiro (Lown \& Ju, 1992). Sobre os impactos do comportamento financeiro, Falahati et al. (2012) afirmam que o mesmo apresenta uma contribuição importante para a satisfação ou insatisfação financeira. Segundo Xiao et al. (2006), Gutter \& Copur (2011) e Delafrooz \& Paim (2011), comportamentos financeiros positivos proporcionam um melhor índice de bem-estar financeiro.

Outro fator relacionado ao bem-estar financeiro corresponde a atitude ao endividamento. Beal e Delpachitra (2003) observaram que baixos níveis de alfabetização financeira ocasionam uso inadequado do cartão de crédito, aumento do consumo e descontrole orçamentário, contribuindo para o endividamento. A atitude ao endividamento é definida por Moura (2005, p. 68) "como o grau de favorabilidade frente ao endividamento", ou seja, o fato do indivíduo possuir mais ou menos características que o tornem vulnerável a gastar mais do que recebe. A autora avaliou fatores que podem determinar a atitude e o comportamento frente as dívidas, estabelecendo três dimensões formadoras da atitude ao endividamento: impacto da moral da sociedade, preferência no tempo e grau de autocontrole.

A dimensão de moral da sociedade relaciona a percepção favorável ou não frente a dívida, abordando questões de socialização econômica e aceitação social. Na preferência no tempo, a atitude ao endividamento relaciona as escolhas nessa decisão, ponderando aspectos de consumo imediato (curto prazo) ou ações de poupança para consumo futuro (longo prazo). Quanto ao grau de autocontrole, Moura (2005) descreve que quanto maior o controle do indivíduo sobre as dimensões financeiras, menor sua atitude ao endividamento.

Como endividamento entende-se um saldo devedor assumido por determinado indivíduo, o qual é gerado a partir da utilização de capital de terceiros. Quando é comprometida uma parcela da renda superior as disponibilidades, surge o sobre- 
endividamento, conceituado como a incapacidade de quitar as dívidas contraídas (Marques \& Frade, 2004).

Sobre causas do endividamento, cita-se como exemplo, perda de emprego e renda, morte do responsável pela renda familiar, gravidez não programada, separação conjugal, mas também pela a falta de planejamento financeiro, levando a ocorrências de compras por impulso, excesso de parcelamento de compras e uso de linhas de crédito de forma impulsiva e descontrolada (Banco Central do Brasil, 2014).

Em relação às consequências do endividamento, Plagnol (2011) afirma que ao acumularem dívidas os indivíduos acabam sofrendo tensão emocional. São apontados também problemas de saúde, estresse e angústia, menor percepção da capacidade de gerenciamento do dinheiro e menor sensação de bem-estar financeiro (Keese \& Schmitz, 2011).

Assim, o gerenciamento dos recursos disponíveis de forma consciente, cumprindo as necessidades financeiras, é o método mais conveniente para a manutenção do bem-estar financeiro (Plagnol, 2011). Xiao et al. (2006) relatam que gestão de caixa, gestão de crédito e questões relativas à poupança são positivamente associados ao bem-estar geral. Sumarwan (1990) também aborda o comportamento de gestão financeira, como pagamento de encargos financeiros, planejamento da utilização do dinheiro, consecução de um orçamento escrito, manutenção/organização de contas e recibos, execução das atividades de gestão no momento em que precisam ser feitas, avaliação de necessidades e discussão sobre finanças. Kim et al. (2003) evidenciam que a gestão financeira fraca ou ineficaz é negativamente relacionada ao bem-estar financeiro.

Por fim, buscou-se identificar a relação entre renda e bem-estar financeiro. Sumarwan (1990), Delafrooz e Paim (2011) e Gutter e Copur (2011) observaram em seus estudos, que a variável renda tem coeficiente significativo e correlação positiva com o bem-estar financeiro. Assim, espera-se que indivíduos que possuem maiores rendimentos e fontes de rendas diversificadas são mais propensos a estarem satisfeitos com a respectiva situação financeira. Vlaev e Elliott (2014) observaram que cerca de 37\% dos entrevistados não consideram possuir um excelente nível de bem-estar financeiro devido a insuficiência de renda. Brow e Gray (2016) sugerem que a posição financeira da família é um determinante relevante para o bem-estar financeiro.

Assim, o alcance do bem-estar financeiro pode estar atrelado, em grande parte a busca pelo conhecimento financeiro e aplicação deste na prática, através de boas atitudes 
financeiras que evitem situações de dívidas. Sabe-se que o nível de renda também é um determinante, no entanto, para se chegar a situação de bem-estar financeiro é necessário equilibrar receitas e despesas, independentemente da circunstância.

\section{Método}

Realizou-se um estudo exploratório, quantitativo, a partir da estratégia de pesquisa survey. A população do estudo compreende as famílias residentes no estado do Rio Grande do Sul, o qual é composto por 497 municípios e possuía uma população total no ano de 2010 de 10.693.929 habitantes (IBGE, 2010). A amostra totalizou 1.577 instrumentos aplicados em nove cidades: Agudo, Erechim, Pelotas, Porto Alegre, Restinga Seca, Santa Maria, Santana do Livramento, Santo Ângelo e São Miguel das Missões.

\section{Coleta de Dados}

O instrumento de coleta de dados foi estruturado em 71 questões divididas em oito blocos. O primeiro foi composto por 21 questões referentes à gestão, decisões, práticas e experiências financeiras pessoais e familiares. A estruturação dessas questões se deu a partir da adaptação de modelos já aplicados por Shockey (2002), OECD (2013b) e Brasil (2009), bem como, pela elaboração de questões inéditas por parte dos pesquisadores, vistas como convenientes ao escopo do trabalho.

O segundo bloco refere-se ao construto bem-estar financeiro estabelecido com 8 questões, que visam identificar o sentimento dos indivíduos em relação à dívida, à preocupação com o cumprimento dos compromissos, situação financeira e perspectivas futuras. Para isso, foram utilizadas as questões elaboradas por Norvilitis et al. (2003) e adequadas a esse estudo. Para mensurar esse construto utilizou-se uma escala do tipo likert de cinco pontos ( 1 - discordo totalmente a 5 - concordo totalmente), em que o maior nível de concordância corresponde à situação de maior bem-estar financeiro. Atenta-se para o fato de que as questões 26, 27, 28 e 29 são invertidas (quanto maior a concordância menor o bem-estar financeiro).

O terceiro bloco, a atitude financeira, baseou-se nas escalas de Shockey (2002) e da OECD (2013b). A escala, composta por 10 questões do tipo likert de cinco pontos (1 discordo totalmente a 5 - concordo totalmente), visa identificar como o indivíduo avalia sua 
gestão financeira. Quanto mais discordar parcial e totalmente das afirmações feitas, melhores são suas atitudes financeiras, salvo as questões 30 e 31 que têm escala invertida.

O quarto bloco, atitude ao endividamento, com nove questões em três aspectos centrais: moral da sociedade, preferência no tempo e auto-controle (Moura, 2005), com uma escala do tipo likert de cinco pontos ( 1 - discordo totalmente a 5 - concordo totalmente), em que quanto maior o ponto assinalado, maior também a atitude ao endividamento. As questões 44, 45, 46, 47 e 48 deste bloco possuem escala invertida.

O comportamento financeiro (quinto bloco) foi obtido com escalas propostas por Shockey (2002), O’Neill e Xiao (2012) e pela OECD (2013b). Foram selecionadas e adaptadas oito para compor o questionário. Ressalta-se que quanto menor a frequência nas afirmações, pior é o seu comportamento no gerenciamento financeiro, refletido através da escala do tipo likert de cinco pontos (1 - nunca a 5 - sempre).

Na sexta parte, expõem-se cinco questões de conhecimento financeiro, adaptadas de Van Rooij et al. (2011), OECD (2013b), Klapper et al. (2013) e National Financial Capability Study (NFCS, 2012). Para mensuração do nível de conhecimento financeiro foi construído um índice com base em Chen e Volpe (1998). O objetivo foi explorar o nível de conhecimento em relação a questões de taxa de juros, risco, retorno e inflação. Conforme pontuação obtida, os respondentes foram classificados como detentores de baixo nível de conhecimento financeiro (pontuação inferior a 60\% do máximo), nível mediano de conhecimento financeiro (entre 60\% e 79\% da pontuação máxima) e alto nível de conhecimento financeiro (acima de 80\% da pontuação máxima). Na última seção estão listadas 10 questões referentes ao perfil: idade, gênero, estado civil, número de dependentes, tipo de moradia, nível de escolaridade, número de pessoas que residem na mesma casa, se trabalham, qual a ocupação, renda mensal familiar.

Essa estrutura foi obtida após a execução de três etapas: tradução reversa, avaliação de especialistas e pré-teste. Os questionários foram aplicados de forma aleatória, em ambiente externo, entre os meses de outubro 2015 e fevereiro de 2016, por meio de contato com pessoas dispostas a participar.

\section{Análise de Dados}

A análise de dados foi realizada em três fases: perfil dos participantes (estatística descritiva), validação dos construtos (Análise Fatorial Confirmatória - AFC) e análise de 
regressão linear múltipla com estimação por Mínimos Quadrados Ordinários (MQO). A validade convergente de cada construto foi analisada pela magnitude e significância estatística dos coeficientes padronizados e pelos índices de ajustes absolutos: estatística quiquadrado $\left(x^{2}\right)$, root mean square residual (RMR), root mean square error of approximation (RMSEA), goodness-of-fit índex (GFI) e índices de ajuste comparativos: comparative fit índex (CFI), normed fit índex (NFI), tucker-lewis índex (TLI). Não há um consenso na literatura sobre valores aceitáveis para esses índices, contudo sugere-se que para o qui-quadrado/graus de liberdade as recomendações devem variar de menores que dois até menores que cinco. Para CFI, GFI, NFI e TLI consideram-se valores maiores que 0,95, e o RMR e o RMSEA devem ficar abaixo de 0,05 e 0,08, respectivamente (Hooper et al., 2008).

Para confiabilidade utilizou-se o índice de confiabilidade e o Alpha de Cronbach, em que valores superiores a o,6 têm sido considerados aceitáveis para pesquisas de natureza exploratória. A verificação da unidimensionalidade do construto foi realizada mediante a avaliação dos resíduos padronizados, sendo que valores absolutos menores que 2,58 não sugerem problema (Hair et al., 2010). Os modelos foram estimados utilizando bootstrap máxima verossimilhança, com tamanho amostral de 1000, conforme sugerido por Cheung e Lau (2008).

A seguir, foram formados os construtos de atitude financeira, comportamento financeiro, atitude ao endividamento e bem-estar financeiro. Para isso, utilizou-se coeficientes padronizados para cada uma das variáveis, ponderando-se o impacto individual na formação de cada construto, através da soma das variáveis multiplicadas pelos seus respectivos pesos.

Diferentemente, o conhecimento financeiro foi consolidado por meio da soma dos acertos individuais. As cinco perguntas tinham apenas uma alternativa correta, sendo cada uma das respostas certas equivalente a 1 ponto. $\mathrm{O}$ fator foi formado pela soma das respostas corretas e erradas de cada entrevistado, sendo a variação da nota de o (errou todas) a 5 (acertou todas).

Por fim, aplicou-se a análise de regressão com o intuito de verificar a influência do gerenciamento financeiro, da renda, da atitude financeira, da atitude ao endividamento, do comportamento financeiro e do conhecimento financeiro sobre o bem-estar financeiro. Este modelo é representado pela equação (1). 
$B F=\alpha+\beta_{1} A F+\beta_{2} A E+\beta_{3} C F+\beta_{4} C o n F+\beta_{5} D 1+\cdots \beta_{16} D 12+u_{i}$

Em (1) BF representa o construto bem-estar financeiro; AF o construto atitude financeira; $\mathrm{AE}$ o construto comportamento financeiro; ConF o índice de conhecimento financeiro. As demais variáveis foram recodificadas em variáveis dummy: D1 refere-se a possuir dívida ( $\mathrm{o}=$ ausência de dívida $\mathrm{e} 1=$ presença $)$; D2 a cartão de crédito ( $\mathrm{O}=$ não possui cartão de crédito e 1 = possui); D3 a carnê de loja (o = não possui carnê de loja e 1 = possui); D4 a poupança ( $\mathrm{o}=$ não possui poupança e $1=$ possui poupança); D5 a cadastro negativo (o $=$ não tem o nome vinculado a um cadastro negativo e $1=$ tem o nome vinculado a um cadastro negativo); D6 a empréstimo do nome (o = não está emprestando o nome e 1 = está emprestando o nome); D7 a conta bancária (o = não possui conta bancária e 1 = possui conta bancária); D8 a controle de gastos (o = não controla e $1=$ controla); D9 a renda 1 (de R $\$$ 1.000,01 à R\$ 3.000,00); D10 a renda 2 (de R\$ 3.000,01 à R\$ 5.000,00); D11 a renda 3 (de $\mathrm{R} \$$ 5.000,01 a R \$ 7.000,00) e D12 a renda 4 (acima de R \$ 7.000,01). A classe de referência para as dummys de renda é a categoria até $\mathrm{R} \$ 1$ 1.000,00. $\alpha$ e $\beta$ são parâmetros estimados e $u_{i}$ é o resíduo do modelo.

Após a estimação, foi calculado o coeficiente de determinação e analisados os pressupostos de normalidade, autocorrelação, multicolinearidade e homocedasticidade do modelo. Para tanto foram utilizados os testes Kolmogorov-Smirnov (KS), Durbin Watson (DW), Fator de Inflação (FIV) e Pesarán-Pesarán, respectivamente. Para verificar a normalidade do erro, utilizou-se o teste KS sob a hipótese nula de que a distribuição da série testada é normal. Corrar et al. (2009) afirmam que o objetivo é aceitar a hipótese nula, sendo que esse fato ocorre sempre que o valor de significância for maior que 0,05. A autocorrelação, por sua vez, foi testada através do teste de DW, que segundo Gujarati e Porter (2011) se constitui no teste mais adequado para identificar a presença de correlação serial.

Com o intuito de se verificar a premissa de multicolinearidade das variáveis, aplicouse o teste VIF, onde até 1 significa sem multicolineariedade, de 1 a 10 , com multicolineariedade aceitável e acima de 10, com multicolineariedade problemática (Corrar et al., 2009). E, por fim, para testar a homocedasticidade, realizou-se o teste de PesaránPesarán, que segundo Corrar et al. (2009), tem por função verificar se a variância do resíduo se mantém constante, onde aceita-se a hipótese nula de que os resíduos são homocedásticos quando o sig for maior que 0,05 . 


\section{Discussão de Resultados}

Tratando-se do perfil, verificou-se que a idade média foi de 32 anos, sendo a maioria $(61,4 \%)$ do gênero feminino, solteira (57,0\%) e que não possuem dependentes (57,4\%). A maior parcela dos entrevistados é assalariado com carteira assinada $(31,4 \%)$ ou funcionário público (18,9\%). Questionados sobre quem trabalha em sua casa, apontaram que ele mesmo trabalha $(81,2 \%)$ e o parceiro(a) trabalha $(38,2 \%)$. Quanto a renda total mensal, indicam maior percentual (15,3\%) na faixa de $\mathrm{R} \$ 1.000,01$ a $\mathrm{R} \$ 2.000,00$. No nível de escolaridade, 43,1\% possuem ensino médio e $28,9 \%$ ensino superior.

Analisando a moradia, declararam viver em casa própria (59,3\%) ou residir em imóvel alugado (24,4\%). Sobre quem mora na casa e possui renda, 71,5\% responderam os pais, $39,8 \%$ o parceiro(a) e $28,5 \%$ os irmãos (múltipla escolha).

Tabela 1

Situação financeira dos respondentes

\begin{tabular}{|c|c|c|}
\hline Variáveis & Alternativas & Percentual \\
\hline \multirow{8}{*}{ Você possui dívidas?* } & Não possuo dívidas. & 38,4 \\
\hline & Tenho com algum banco/financeira. & 33,5 \\
\hline & Tenho no supermercado do bairro. & 6,7 \\
\hline & Tenho com amigos e/ou colegas. & 4,8 \\
\hline & Tenho com lojas de crediário próprio. & 24,8 \\
\hline & Tenho com agiotas. & 0,3 \\
\hline & Tenho com familiares. & 6,9 \\
\hline & Tenho com outros. & 4,6 \\
\hline \multirow{3}{*}{$\begin{array}{l}\text { Você já teve ou tem seu nome } \\
\text { ligado ao cadastro negativo? }\end{array}$} & Não. & 63,0 \\
\hline & Sim, já tive no passado. & 22,8 \\
\hline & Sim, tenho atualmente. & 14,2 \\
\hline \multirow{3}{*}{$\begin{array}{c}\text { Você já emprestou seu nome para } \\
\text { outra pessoa realizar alguma } \\
\text { compra? }\end{array}$} & Não. & 55,3 \\
\hline & Sim, já emprestei. & 40,3 \\
\hline & Sim, estou emprestando. & 4,4 \\
\hline \multirow{6}{*}{ Você tem conta em algum banco? } & Não possuo conta. & 13,4 \\
\hline & Só possuo conta poupança. & 10,0 \\
\hline & Só possuo conta corrente. & 22,5 \\
\hline & Só possuo conta salário. & 6,6 \\
\hline & Possuo conta corrente e poupança. & 36,4 \\
\hline & Possuo conta corrente, conta salário e poupança. & 11,2 \\
\hline \multirow{4}{*}{$\begin{array}{l}\text { Na sua casa, alguém possui cartão } \\
\text { de crédito?* }\end{array}$} & Não. & 21,9 \\
\hline & Sim, eu tenho. & 62,8 \\
\hline & Sim, outra pessoa tem. & 28,1 \\
\hline & Não sei. & 0,8 \\
\hline \multirow{2}{*}{$\begin{array}{c}\text { Na sua casa, alguém possui carnê } \\
\text { de crediário?* }\end{array}$} & Não. & 46,8 \\
\hline & Sim, eu tenho. & 35,4 \\
\hline
\end{tabular}


Fonte: Dados da pesquisa.

Sim, outra pessoa tem. 17,6

Não sei.

*O somatório é superior a 100\% pois os entrevistados poderiam selecionar mais de uma alternativa.

Salientando os principais resultados, quando os entrevistados foram questionados se possuem dívidas ou não, 38,4\% dizem não tê-las, enquanto 33,5\% dizem ter dívida com algum banco ou financeira. A respeito de ter o nome ligado ao cadastro negativo, 63\% não têm e $22,8 \%$ o tiveram no passado. Esses números representam que dentre os entrevistados o endividamento não está levando a níveis elevados de inadimplência. Quanto ao empréstimo do nome, a maioria apontou que não emprestou o nome para outra pessoa realizar alguma compra (55,3\%). A classe com maior frequência encontrada mostra que $36,4 \%$ possuem conta corrente e poupança, enquanto $22,5 \%$ têm apenas conta corrente. A maioria dos entrevistados utilizam cartão de crédito $(62,8 \%)$ e $21,9 \%$ declararam que ninguém na sua casa possui cartão de crédito. De maneira geral, esses percentuais indicam que os respondentes estão incluídos financeiramente (por meio da conta corrente, cartão de crédito e crediário), resultado que indica a facilidade de acesso ao crédito também evidenciada por Spc (2016). A Tabela 2 aborda os gastos familiares dos respondentes.

Tabela 2

Controle dos gastos familiares

\begin{tabular}{|c|c|c|}
\hline Variáveis & Alternativas & Percentual \\
\hline \multirow{6}{*}{$\begin{array}{l}\text { Em quanto tempo os } \\
\text { recursos da sua família são } \\
\text { gastos? }\end{array}$} & Quando recebo já estou com todo o dinheiro gasto. & 16,4 \\
\hline & Em uma semana. & 11,7 \\
\hline & Em duas semanas. & 10,6 \\
\hline & Em três semanas. & 13,1 \\
\hline & Em um mês. & 29,3 \\
\hline & Em mais de um mês. & 18,9 \\
\hline \multirow{3}{*}{$\begin{array}{l}\text { Com relação aos seus } \\
\text { gastos, você diria que: }\end{array}$} & Gasto mais do que ganho. & 23,8 \\
\hline & Gasto igual ao que ganho. & 42,7 \\
\hline & Gasto menos do que ganho. & 33,5 \\
\hline \multirow{6}{*}{$\begin{array}{c}\text { Na sua casa, quem decide } \\
\text { como vai ser gasto o } \\
\text { dinheiro: }\end{array}$} & Eu. & 46,6 \\
\hline & Meu(a) parceiro(a). & 1,5 \\
\hline & Eu e meu(a) parceiro(a). & 30,7 \\
\hline & Meus filhos e/ou netos. & 0,4 \\
\hline & Meus pais. & 19,5 \\
\hline & Outro membro da família. & 1,2 \\
\hline \multirow{4}{*}{$\begin{array}{c}\text { Por que essas pessoas } \\
\text { decidem como/onde } \\
\text { gastar o dinheiro da casa? }\end{array}$} & Porque são os responsáveis. & 42,8 \\
\hline & Porque são os que trabalham. & 14,7 \\
\hline & Porque são os que ganham mais. & 2,9 \\
\hline & Porque contribuem financeiramente. & 7,7 \\
\hline
\end{tabular}


Qual das seguintes afirmações MELHOR descreve o quanto você controla os seus gastos regulares?
Porque estudam/entendem melhor de contas.

Porque sabem o que precisa comprar. Outro motivo.

Não sei.

Não costumo controlar meus gastos.

Mantenho um pequeno controle sobre meus gastos.

Não mantenho escrito, mas controlo os gastos.

Utilizo anotações por escrito para manter um maior controle sobre os gastos.
1,8 26,2 2,0 1,9 7,7 26,7 32,1 33,5

Fonte: Dados da pesquisa.

Ao verificar em quanto tempo os recursos são gastos, 29,3\% disse em um mês. Quanto aos gastos, 42,7\% declarou que gasta igual ao que ganha, resultado que reflete a dificuldade de boa parte dos entrevistados para realizarem economias, corroborado com os dados apresentados por Spc (2016). Também informaram quem decide como vai ser gasto o dinheiro da casa, e 46,6\% disse que ele mesmo decide, enquanto para 30,7\% a decisão é tomada por ele e pelo parceiro(a). Essas pessoas contribuem, pois são responsáveis (42,8\%) e porque sabem as necessidades da casa (26,2\%). Referente ao controle de gastos, constatouse que o mesmo existe, porém nem sempre ocorre de maneira padronizada, pois 33,5\% respondeu que utiliza anotações por escrito para manter um maior controle, enquanto 32,1\% não mantêm escrito, mas controla-os. A Tabela 3 apresenta a atitude em relação aos gastos.

Tabela 3

Atitude em relação aos gastos

\begin{tabular}{|c|c|c|}
\hline Variáveis & Alternativas & Percentual \\
\hline \multirow{11}{*}{$\begin{array}{l}\text { No dia em que você } \\
\text { recebe seu salário, o } \\
\text { que você faz } \\
\text { PRIMEIRO? }\end{array}$} & Pago minhas dívidas. & 39,5 \\
\hline & Compro material escolar para as crianças. & 2,0 \\
\hline & Compro passagens para o transporte. & 1,4 \\
\hline & Compro remédios. & 0,9 \\
\hline & Compro alimentos. & 8,9 \\
\hline & Pago as contas de água/luz/gás/aluguel. & 33,6 \\
\hline & Compro roupas/calçados/créditos para o celular. & 1,2 \\
\hline & Compro bebidas alcoólicas/cigarro. & 0,3 \\
\hline & Compro bens duráveis. & 0,1 \\
\hline & Guardo o dinheiro. & 9,2 \\
\hline & Outros. & 3,0 \\
\hline \multirow{7}{*}{$\begin{array}{l}\text { Quando sobra } \\
\text { dinheiro no final do } \\
\text { mês, o que você } \\
\text { costuma fazer? }\end{array}$} & Nunca sobra dinheiro. & 16,3 \\
\hline & Compro mais alimento. & 6,6 \\
\hline & Gasto com lazer. & 20,9 \\
\hline & Invisto no negócio ou no aumento da produção. & 2,2 \\
\hline & Faço uma reforma/ampliação da casa. & 1,5 \\
\hline & Pago prestações. & 3,8 \\
\hline & Guardo o dinheiro para gastos futuros. & 42,5 \\
\hline
\end{tabular}




\begin{tabular}{|c|c|c|}
\hline & Compro roupas e calçados. & 4,6 \\
\hline & Outro. & 1,5 \\
\hline \multirow{5}{*}{$\begin{array}{l}\text { O que você faz } \\
\text { quando não tem } \\
\text { dinheiro e surge uma } \\
\text { necessidade? }\end{array}$} & Compro fiado. & 9,1 \\
\hline & Peço dinheiro emprestado para amigo/familiar. & 49,2 \\
\hline & Peço dinheiro ao banco ou a uma financeira. & 8,2 \\
\hline & Peço para algum conhecido comprar no nome dele. & 3,5 \\
\hline & Utilizo o limite do cartão de crédito. & 30,0 \\
\hline \multirow{10}{*}{$\begin{array}{l}\text { Você faz algum tipo } \\
\text { de poupança?*}\end{array}$} & Não, nunca fiz. & 26,2 \\
\hline & Não, mas já fiz. & 24,0 \\
\hline & Sim, em dinheiro em casa. & 5,0 \\
\hline & Sim, em dinheiro no banco/caderneta de poupança. & 40,7 \\
\hline & Sim, em animais, sementes e/ou outros produtos. & 1,0 \\
\hline & Sim, em estoque/equipamentos do negócio. & 0,6 \\
\hline & Sim, em fundos de investimento. & 3,4 \\
\hline & Sim, em títulos do tesouro direto. & 0,9 \\
\hline & Sim, em ações. & 0,6 \\
\hline & Sim, de outra forma. & 0,9 \\
\hline
\end{tabular}

Fonte: Dados da pesquisa.

*O somatório é superior a 100\% pois os entrevistados poderiam selecionar mais de uma alternativa.

Na primeira ação após o recebimento, boa parte da amostra $(39,5 \%)$ disse que paga suas dívidas e outro percentual representativo dá prioridade apenas para as contas de serviços básicos, como água, luz, gás e/ou aluguel (33,6\%). Quando sobra dinheiro no final do mês, um número bastante expressivo (42,5\%) guarda o valor para gastos futuros, enquanto 20,9\% gasta com lazer. Quando não tem dinheiro, 49,2\% afirmaram pedir dinheiro emprestado para amigos ou familiares e 30\% utilizam o limite do cartão de crédito. Este resultado vai ao encontro de informações disponibilizadas pelo Spc (2016), que afirma que o cartão de crédito é uma das principais modalidades de pagamento usadas pelos consumidores e que estes possuem uma média de dois cartões por pessoa. Dos respondentes, 40,7\% realizam poupança em dinheiro na caderneta de poupança, enquanto outros nunca fizeram algum tipo de poupança (20,6\%). Esses dados representam que a poupança é o investimento preferido perante os pesquisados, sendo pouco representativos os demais meios de investimento, como exemplo ações, seja pelo motivo de desconhecimento, falta de dinheiro, baixa renda e/ou medo do risco. A Tabela 4 mostra a satisfação com a situação financeira.

Tabela 4

Satisfação com a situação financeira 


\begin{tabular}{|c|c|c|}
\hline \multirow{5}{*}{ Você considera a sua renda: } & Muito baixa & 22,6 \\
\hline & Suficiente & 33,2 \\
\hline & Média & 38,2 \\
\hline & Alta & 5,8 \\
\hline & Muito alta & 0,3 \\
\hline \multirow{5}{*}{$\begin{array}{l}\text { Nos últimos anos, a sua vida } \\
\text { financeira: }\end{array}$} & Piorou muito & 2,4 \\
\hline & Piorou & 12,3 \\
\hline & Continua igual & 22,4 \\
\hline & Melhorou & 54,1 \\
\hline & Melhorou muito & 8,8 \\
\hline \multirow{5}{*}{$\begin{array}{l}\text { No geral, quanto satisfeito você está } \\
\text { com a sua situação financeira? }\end{array}$} & Totalmente insatisfeito & 6,0 \\
\hline & Insatisfeito & 36,7 \\
\hline & Indiferente & 12,3 \\
\hline & Satisfeito & 43,1 \\
\hline & Totalmente satisfeito & 1,9 \\
\hline
\end{tabular}

Fonte: Dados da pesquisa.

Quanto à renda, 38,2\% consideram sua renda média, enquanto 33,2\% a consideram suficiente e 22,6\% muito baixa. Os números refletem em geral, que dentre os entrevistados a renda não é considerada alta ou muito alta. Mesmo assim, a maioria $(54,1 \%)$ acredita que sua vida financeira melhorou nos últimos anos, enquanto para 22,4\% continua igual. Em relação a satisfação com a situação financeira, 43,1\% disse estar satisfeito, ao passo que $36,7 \%$ está insatisfeito.

Após conhecer o gerenciamento financeiro, avaliou-se os resultados dos construtos. A estatística descritiva dos mesmos é ilustrada no Apêndice, sendo a descrição das variáveis mais significativas apresentadas na sequência. $\mathrm{Na}$ atitude financeira, a variável que alcançou maior média $(4,47)$ foi "Para você, é importante definir metas para o futuro". Trata-se de uma variável invertida (quanto maior a média, melhor é a atitude financeira), e pode-se inferir que a meta contribui para que os indivíduos se empenhem mais para poupar recursos, e então, alcançarem seus objetivos, levando a um maior bem-estar financeiro. A menor média (1,93), foi "Você não se preocupa com o futuro, vive apenas o presente", o que mostra uma boa atitude financeira, e tende a levar a um comportamento financeiro ideal, marcado pela gestão financeira eficaz (O’Neill \& Xiao, 2012). No comportamento financeiro, "Você analisa suas contas antes de fazer uma compra grande” alcançou a maior média $(4,57)$, mostrando que os respondentes têm consciência da importância de planejar gastos. A menor média $(2,86)$ foi da variável "Nos últimos 12 meses, você tem conseguido poupar dinheiro", mostrando certa dificuldade em poupar. 
Para Atitude ao Endividamento a maior média $(4,41)$ foi "É importante saber controlar os gastos da sua casa", enquanto "Você prefere pagar parcelado mesmo que no total saia mais caro" obteve menor média $(2,17)$. Variáveis invertidas alcançaram maiores médias, mostrando que os indivíduos possuem baixa atitude ao endividamento, sabem controlar seus gastos e boa parte deles reconhece ser melhor comprar à vista do que parcelado.

Para o bem-estar financeiro identificou-se que "Daqui a 5 anos, você pretende ter pago todas as suas dívidas" alcançou a maior média $(3,96)$, mostrando que estão otimistas com sua situação. A menor média $(2,26)$ foi "Você tem tido discussões com outras pessoas (pais, amigos, esposo(a) e outros) devido à sua dívida”, porém a média já reflete às consequências do endividamento, como a tensão emocional que pode ser causada por discussões familiares (Plagnol, 2011). Prosseguindo, buscou-se analisar o conhecimento financeiro dos respondentes, a fim de averiguar o nível de acertos nas variáveis selecionadas (Tabelas 5 e 6).

Tabela 5

Frequência e percentual válido do construto Conhecimento Financeiro

\begin{tabular}{|c|c|c|c|}
\hline Código & Variáveis & Alternativas & Percentual \\
\hline \multirow{4}{*}{$\mathrm{IC} 1$} & \multirow{4}{*}{$\begin{array}{l}\text { Suponha que você tenha } \mathrm{R} \$ 100,00 \text { em } \\
\text { uma conta poupança a uma taxa de } \\
\text { juros de } 10 \% \text { ao ano. Depois de } 5 \text { anos, } \\
\text { qual o valor que você terá na } \\
\text { poupança? Considere que não tenha } \\
\text { sido depositado e nem retirado } \\
\text { dinheiro. }\end{array}$} & Mais do que $\mathrm{R} \$ 150,00 .{ }^{*}$ & 48,5 \\
\hline & & Exatamente R \$ 150,o0. & 28,5 \\
\hline & & Menos do que R\$150,00. & 6,5 \\
\hline & & Não sei. & 16,5 \\
\hline \multirow{4}{*}{$\mathrm{IC} 2$} & \multirow{4}{*}{$\begin{array}{l}\text { Suponha que no ano de } 2016 \text { sua renda } \\
\text { dobrará e os preços de todos os bens } \\
\text { também dobrarão. Em 2016, o quanto } \\
\text { você será capaz de comprar com a sua } \\
\text { renda? }\end{array}$} & Mais do que hoje. & 10,7 \\
\hline & & Exatamente o mesmo.* & 61,2 \\
\hline & & Menos do que hoje. & 17,1 \\
\hline & & Não sei. & 11,0 \\
\hline \multirow{5}{*}{$\mathrm{IC}_{3}$} & \multirow{5}{*}{$\begin{array}{l}\text { Imagine que cinco amigos recebem } \\
\text { uma doação de } \mathrm{R} \$ 1 \text { 1.ooo,oo e precisam } \\
\text { dividir o dinheiro igualmente entre } \\
\text { eles. Quanto cada um vai obter? }\end{array}$} & $\mathrm{R} \$ 100,00$. & 1,2 \\
\hline & & $\mathrm{R} \$ 200,00 . *$ & 86,8 \\
\hline & & $\mathrm{R} \$ 1.000,00$. & 3,5 \\
\hline & & $\mathrm{R} \$ 5.000,00$. & 0,6 \\
\hline & & Não sei. & 7,8 \\
\hline \multirow{3}{*}{$\mathrm{IC}_{4}$} & \multirow{3}{*}{$\begin{array}{l}\text { Um investimento com alta taxa de } \\
\text { retorno terá alta taxa de risco. Essa } \\
\text { afirmação é: }\end{array}$} & Verdadeira.* & 66,5 \\
\hline & & Falsa. & 11,2 \\
\hline & & Não sei. & 22,3 \\
\hline \multirow{3}{*}{$\mathrm{IC}_{5}$} & \multirow{3}{*}{$\begin{array}{l}\text { Alta inflação significa que o custo de } \\
\text { vida está subindo rapidamente. Essa } \\
\text { afirmação é: }\end{array}$} & Verdadeira.* & 85,8 \\
\hline & & Falsa. & 6,2 \\
\hline & & Não sei. & 8,1 \\
\hline
\end{tabular}


Fonte: Dados da pesquisa.

${ }^{*}$ Respostas corretas.

As alternativas que obtiveram maior percentual foram as respostas corretas. É importante destacar que na questão "IC1", 28,5\% dos respondentes assinalou que teria exatamente $\mathrm{R} \$ 150,00$, mostrando que podem não compreender com tanta clareza o funcionamento dos juros compostos. A Tabela 6 mostra o número de acertos dos respondentes.

Tabela 6

Número de acertos dos respondentes para o construto Conhecimento Financeiro

\begin{tabular}{|c|c|c|c|c|c|}
\hline Número de acertos & Frequência & Percentual válido & Porcentual de acertos & Classificação* & Acumulado \\
\hline $\mathrm{O}$ & 69 & 4,4 & O\% & Baixo & \multirow{4}{*}{$44,20 \%$} \\
\hline 1 & 93 & 5,9 & $20 \%$ & Baixo & \\
\hline 2 & 165 & 10,5 & $40 \%$ & Baixo & \\
\hline 3 & 369 & 23,4 & $60 \%$ & Baixo & \\
\hline 4 & 507 & 32,1 & $80 \%$ & Médio & $32,10 \%$ \\
\hline 5 & 374 & 23,7 & $100 \%$ & Alto & $23,70 \%$ \\
\hline
\end{tabular}

Fonte: Dados da pesquisa.

*Classificação baseada no modelo de Chen e Volpe (1998).

Segundo classificação de Chen e Volpe (1998), as pontuações indicam um baixo nível de conhecimento financeiro para 44,20\%, um conhecimento médio para 32,10\% e conhecimento alto em 23,70\%. Após a análise descritiva dos construtos partiu-se para a etapa de validação. O processo compreendeu a Análise Fatorial Confirmatória (AFC), com o suporte do Amos $^{\mathrm{TM}}$. As Tabelas 7 e 8 resumem os resultados dos modelos iniciais e dos modelos finais.

Tabela 7

Índices de ajuste dos construtos: modelos iniciais

\begin{tabular}{lcccc}
\hline $\begin{array}{c}\text { Índices de ajuste } \\
\text { Modelos iniciais }\end{array}$ & $\begin{array}{c}\text { Atitude } \\
\text { Financeira }\end{array}$ & $\begin{array}{c}\text { Atitude ao } \\
\text { Endividamento }\end{array}$ & $\begin{array}{c}\text { Comportamento } \\
\text { Financeiro }\end{array}$ & $\begin{array}{c}\text { Bem-Estar } \\
\text { Financeiro }\end{array}$ \\
\hline Número de variáveis & 10 & 09 & 08 & 08 \\
\hline Qui-quadrado (valor) & 987,882 & 530,411 & 676,525 & 1855,936 \\
\hline Qui-quadrado (probabilidade) & 0,000 & 0,000 & 0,000 & 0,000 \\
\hline Graus de Liberdade & 35 & 27 & 20 & 20 \\
\hline
\end{tabular}




\begin{tabular}{lcccc} 
Qui-quadrado/Graus de Liberdade & 28,225 & 19,644 & 33,826 & 92,796 \\
\hline GFI & 0,865 & 0,926 & 1,000 & 0,755 \\
\hline CFI & 0,539 & 0,722 & 0,758 & 0,486 \\
\hline NFI & 0,532 & 0,713 & 0,753 & 0,485 \\
\hline TLI & 0,407 & 0,629 & 0,661 & 0,281 \\
\hline RMR & 0,119 & 0,062 & 0,000 & 0,199 \\
\hline RMSEA & 0,131 & 0,109 & 0,144 & 0,241 \\
\hline Índice de Confiabilidade & 0,640 & 0,600 & 0,760 & 0,570 \\
\hline Alpha de Cronbach & 0,560 & 0,620 & 0,750 & 0,580 \\
\hline
\end{tabular}

Fonte: Dados da pesquisa.

Nos procedimentos de validação foram considerados os índices de ajuste e confiabilidade, observando os limites indicados por Hooper et al. (2008), Hair et al. (2010) e Kline (2011). A validade convergente expressa pelos índices de ajuste absolutos encontrase fora dos padrões desejados em todos os construtos. Ao analisar a confiabilidade (índice de confiabilidade e Alpha de Cronbach), é possível destacar valores mais elevados nos construtos de atitude financeira e comportamento financeiro.

Para atingir níveis satisfatórios, procedimentos de ajuste foram adotados, conforme os critérios: retirada de variáveis não significativas, exclusão de coeficientes baixos (menor que o,5), indicações de modificação de índices do software AMOS e inclusão de correlações, sendo os construtos validados (Tabela 8).

Tabela 8

Índices de ajuste dos construtos: modelos finais

\begin{tabular}{lllll}
\hline $\begin{array}{l}\text { Indices de ajuste } \\
\text { Modelos finais }\end{array}$ & $\begin{array}{l}\text { Atitude } \\
\text { Financeira }\end{array}$ & $\begin{array}{l}\text { Atitude } \\
\text { Endividamento }\end{array}$ & $\begin{array}{l}\text { ao } \\
\text { Financeiro }\end{array}$ & $\begin{array}{l}\text { Bem-Estar } \\
\text { Financeiro }\end{array}$ \\
\hline Número de variáveis & 03 & 03 & 03 & 04 \\
\hline Qui-quadrado (valor) & 4,293 & 5,750 & 2,992 & 2,079 \\
\hline Qui-quadrado (probabilidade) & 0,038 & 0,016 & 0,084 & 0,149 \\
\hline Graus de Liberdade & 01 & 01 & 01 & 01 \\
\hline Qui-quadrado/Graus de Liberdade & 4,293 & 5,750 & 2,992 & 2,079 \\
\hline GFI & 0,998 & 0,998 & 0,999 & 0,999 \\
\hline CFI & 0,993 & 0,995 & 0,997 & 0,999 \\
\hline NFI & 0,991 & 0,993 & 0,996 & 0,999 \\
\hline TLI & 0,980 & 0,984 & 0,992 & 0,996 \\
\hline RMR & 0,016 & 0,017 & 0,017 & 0,007 \\
\hline RMSEA & 0,046 & 0,055 & 0,036 & 0,026 \\
\hline Índice de Confiabilidade & 0,720 & 0,760 & 0,760 & 0,700 \\
\hline Alpha de Cronbach & 0,600 & 0,640 & 0,660 & 0,700 \\
\hline
\end{tabular}

Fonte: Dados da pesquisa. 
Identificou-se a validação por base na relação Qui-Quadrado/Graus de Liberdade que encontra-se inferior ou igual a 5, corroborando com Hooper et al. (2008) e Hair et al. (2010). Confirmou-se a confiabilidade (resultados superiores ao valor mínimo de o,6) e validade convergente, dado que os índices CFI, GFI, NFI e TLI foram superiores a 0,95 e os índices RMR e RMSEA foram inferiores a 0,05 e 0,08, respectivamente. Analisando o perfil dos construtos, na atitude financeira tem-se uma tendência ao risco, visto que as variáveis constituem uma visão de curto prazo, sem preocupações futuras com poupança e voltadas ao consumo imediato do dinheiro (AF10: Para você o dinheiro foi feito para gastar coeficiente 0,695; AF9: Você considera mais satisfatório gastar dinheiro do que poupar para o futuro - coeficiente 0,$625 ; \mathrm{AF}_{3}$ : Você não se preocupa com o futuro, vive apenas o presente - coeficiente 0,407$)$.

$\mathrm{Na}$ Atitude ao Endividamento, o construto foi formado por três questões, cabendo salientar que a estatística qui-quadrado foi aceitável em seu percentual, não sendo significativo ao nível de $1 \%$. Identificou-se atitude positiva ao endividamento a partir validação. (AE2: Você prefere comprar parcelado do que esperar ter dinheiro para comprar à vista - coeficiente 0,812 ; AE3: Você prefere pagar parcelado mesmo que no total saia mais caro - coeficiente 0,758; AE1: Para você, é normal as pessoas ficarem endividadas para pagar suas contas - coeficiente 0,315 ).

No comportamento financeiro identificou-se três variáveis significativas, as quais contemplam a utilização de planilhas financeiras, controle de gastos e orçamento, além da comparação de preços ao fazer uma compra (CF3: Você tem um plano de gastos/orçamento - coeficiente 0,732; CF1: Você anota e controla os seus gastos (ex: com planilha) coeficiente 0,731; CF2: Você compara preços ao fazer uma compra - coeficiente 0,454). Percebe-se um grau de importância mais elevado na elaboração do plano de gastos/orçamento e comparação de preços.

O bem-estar financeiro foi elucidado por quatro variáveis, sendo as mesmas um questionamento da satisfação financeira e do nível de dívidas. Visualiza-se maior significância para formação do construto das variáveis "Você se sente financeiramente satisfeito" (coeficiente: 0,777) e "Você acredita estar em uma boa situação financeira" (coeficiente: 0,946). As demais estavam relacionadas ao sentimento da dívida, sendo inserida uma correlação entre os erros das variáveis, evidenciando estarem no mesmo sentido quanto ao sentimento de bem-estar financeiro. Nessa dimensão, cita-se as variáveis 
"Você se sente desconfortável com a quantia que deve" (coeficiente: 0,285 ) e "Você pensa muito em suas dívidas” (coeficiente: 0,324).

$\mathrm{Na}$ sequência foram elaborados os construtos de atitude financeira, comportamento financeiro, atitude ao endividamento e bem-estar financeiro. Assim, os fatores foram calculados a partir das médias ponderadas das variáveis que os compõem. A ponderação foi realizada considerando o coeficiente padronizado de cada variável na validação do construto. Já o conhecimento financeiro foi consolidado por meio da soma dos acertos de cada indivíduo, sendo a variação da nota de o (errou todas as questões) a 5 (acertou todas). A Tabela 9 exibe a estatística descritiva dos fatores e do índice de conhecimento financeiro.

Tabela 9

Estatística descritiva dos fatores e do índice de conhecimento financeiro

\begin{tabular}{lcc}
\hline Construto & Média & Mediana \\
\hline Atitude ao Endividamento & 2,375 & 2,314 \\
Atitude Financeira & 2,460 & 2,402 \\
Comportamento Financeiro & 3,424 & 3,474 \\
Bem-Estar Financeiro & 2,799 & 2,739 \\
Conhecimento Financeiro & 3,442 & 4,000 \\
\hline
\end{tabular}

Fonte: Dados da pesquisa.

De maneira geral, a média dos construtos ratifica o baixo nível de atitude ao endividamento, ou seja, os indivíduos obtiveram baixa favorabilidade a dívida, visto que discordaram (média próxima a 2) das questões que envolvem maior parcelamento e utilização do crédito. Consideração a existência de uma atitude ao endividamento mais baixa, os respondentes evidenciaram preocupação positiva com suas atitudes financeiras. Assim, também discordaram (média 2,460) de questões que demonstram aspectos de consumo imediato e com poucas preocupações futuras. No mesmo sentido, esperava-se que o comportamento financeiro obtivesse média mais elevada (maior média, melhor comportamento financeiro), devido ao construto ser caracterizado por aspectos de planejamento, orçamento e controle dos gastos. Contudo, o comportamento financeiro resultou em um nível intermediário, sendo que parte dos indivíduos se comporta de forma adequada financeiramente, mas outra parte não.

O índice de conhecimento financeiro e o bem-estar financeiro também direcionam ao nível médio. Com isso, o presente estudo mostra que os respondentes possuem elementos 
que contribuem para o bem-estar financeiro, tais como atitude ao endividamento, atitude, conhecimento e comportamento financeiros, corroborando a OECD (2015), Norvilitis et al. (2003), Xiao et al. (2006), Gutter e Copur (2011), Delafrooz e Paim (2011) e Lown e Ju (1992). No entanto, ainda é necessário aperfeiçoar esses fatores para que se possa alcançar menores coeficientes de dívidas e maior sensação de bem-estar financeiro. Na etapa final, realizou-se uma regressão linear múltipla com estimação por Mínimos Quadrados Ordinários (MQO) e o método Enter (Tabela 10).

Tabela 10

Resultados da regressão linear múltipla estimada para o bem-estar financeiro

\begin{tabular}{lc|c}
\hline Variáveis & $\begin{array}{c}\text { Coefientes } \\
\text { Padronizados }\end{array}$ & VIF \\
\hline Atitude ao Endividamento & $-0,016$ & 1,284 \\
Comportamento Financeiro & $0,045^{* *}$ & 1,183 \\
Atitude Financeira & $-0,044$ & 1,209 \\
Conhecimento Financeiro & 0,063 & 1,330 \\
Possuir dívidas* & $-0,151^{* *}$ & 1,228 \\
Cartão de crédito* & $0,045^{*}$ & 1,576 \\
Carnê de loja* & $-0,049^{* *}$ & 1,137 \\
Poupança* & $0,228^{* *}$ & 1,415 \\
Nome ligado ao cadastro negativo* & $-0,145^{* *}$ & 1,335 \\
Empréstimo do nome* & $-0,010$ & 1,032 \\
Conta bancária* & $-0,051^{* * *}$ & 1,376 \\
Controle de gastos* & 0,039 & 1,152 \\
Renda $1^{*}$ & $-0,014$ & 2,482 \\
Renda $2^{*}$ & 0,060 & 2,559 \\
Renda $3^{*}$ & $0,078^{* * *}$ & 2,091 \\
Renda 4* & $0,188^{* *}$ & 2,757 \\
\hline
\end{tabular}

Fonte: Dados da pesquisa.

*representam variáveis dummy.

** $\mathrm{e}^{* * *}$ representam nível de significância estatística a 1\% e 5\% respectivamente.

O resultado apresenta oito variáveis independentes significativas ao nível de $5 \%$, com um $\mathrm{R}^{2}$ ajustado de 0,247 , ou seja, 24,7\% da variável dependente é explicada. O teste $\mathrm{F}$ foi significativo ao nível de $1 \%$, indicando que pelo menos uma das variáveis independentes exerce influência sobre a variável dependente.

Quanto aos pressupostos, como os resíduos apresentaram heterocedasticidade a partir do teste Pesarán-Pesarán (rejeitou-se a hipótese nula, sig.<0,05), utilizou-se o estimador White Heteroskedasticity Consistent - HCo para estimativa robusta frente a problemas de 
heterocedasticidade nos erros (White, 1980). Observou-se que não há autocorrelação serial, uma vez que o valor do teste de DW $(1,831)$ ficou próximo de 2; o modelo não apresenta problemas de multicolinearidade (VIFs ficaram entre 1 e 10); os resíduos possuem distribuição normal (KS não foi significativo - sig. 0,099).

Analisando-se os coeficientes e a direção da relação, constatou-se que as variáveis: comportamento financeiro, dummy poupança, dummy renda 3 (de $\mathrm{R} \$ 5.000,01$ a $\mathrm{R} \$$ 7.000,00) e dummy renda 4 (acima de $\mathrm{R} \$$ 7.000,01) mostraram-se significativas, exercendo influência positiva no bem-estar financeiro. A maior influência está nas dummys poupança $(0,228)$ e renda $4(0,188)$, corroborando com estudos de comportamento e hábitos de poupança (Shim et al., 2009; Delafrooz \& Paim, 2011; Gutter \& Copur, 2011; Falahati et al., 2012) e relação entre renda e BEF (Gutter \& Copur, 2011; Diniz et al., 2014; Vlaev \& Elliott, 2014; Brow \& Gray, 2016). Ainda, a maior renda está atrelada a maior bem-estar financeiro, pois quando se tem mais recursos disponíveis, os indivíduos tendem a apresentar com mais frequência alguns dos elementos inerentes ao bem-estar financeiro. Também por isso, infere-se a ocorrência da não significância das dummys renda 1 e 2.

As dummys possuir dívidas, carnê de loja, nome ligado ao cadastro negativo e conta bancária também influenciaram no bem-estar financeiro, contudo essa relação é negativa. Resultados atrelados ao fato de que a inclusão financeira, por meio de conta bancária, crédito, compras parceladas, pode expor o indivíduo ao consumo excessivo, níveis elevados de dívida e sobreendividamento. A literatura (Shim et al., 2009; Keese \& Schmitz, 2011; Plagnol, 2011; Diniz et al., 2014) relaciona esses aspectos, e o endividamento em si com uma menor sensação de bem-estar financeiro.

Com relação às dummys cartão de crédito, empréstimo do nome e controle de gastos não serem significativas do modelo, pode ser explicado pelo fato de que os estudos de Beal \& Delpachitra (2003) e Banco Central do Brasil (2014) evidenciam que essas variáveis são possíveis causas de possuir dívidas, dummy que apresentou-se significativa no modelo. Logo, elas podem influenciar o endividamento, mas não interferem diretamente no BEF. Além disso, possuir atraso no pagamento do cartão de crédito pode aumentar o endividamento e causar impacto no bem-estar financeiro, contudo a dummy cartão de crédito refere-se apenas se o indivíduo o possui ou não, não levando em consideração como ele o utiliza. Assim como empréstimo do nome, em que o indivíduo que utilizou o nome de outro, paga as contas em dia, não alterando o bem-estar financeiro de quem o emprestou. 


\section{Conclusões}

Tendo em vista o ambiente econômico do país, temas que envolvem consumo, gestão e planejamento tornam-se essenciais para determinar o bem-estar financeiro pessoal. Assim, buscou-se analisar a influência dos fatores comportamentais e renda no bem-estar financeiro dos indivíduos, além de ser realizada uma análise sobre o nível de alfabetização financeira, atitude ao endividamento, características do gerenciamento financeiro e bemestar financeiro dos entrevistados e serem validados os construtos comportamentais investigados.

Verificou-se que o bem-estar financeiro pode ser influenciado pelas variáveis: comportamento financeiro, possuir dívidas, carnê de loja, poupança, nome ligado ao cadastro negativo, conta bancária e renda acima de $\mathrm{R}$ \$5.000,01. Mais especificamente, em relação ao comportamento financeiro, esse está intimamente ligado as ações dos indivíduos, que muitas vezes são moldadas pelos recursos disponíveis no momento e independem do que os mesmos acham que seria mais adequado para o bem-estar financeiro, além de representar a dimensão mais concreta da alfabetização financeira.

Quanto as dívidas, mesmo quando há condições de pagamento do momento de adquiri-las, há o peso da responsabilidade financeira, além da possível ocorrência de imprevistos e a preocupação constante com o pagamento. Contudo, essa preocupação pode ser evitada com a ato de poupar, onde os indivíduos tendem a acumular mais recursos e estarem preparadas para situações adversas, garantindo o pagamento de dívidas e o maior bem-estar com as finanças. $\mathrm{O}$ fato de possuir o nome ligado ao cadastro negativo também influencia o bem-estar financeiro pois leva a diminuição ou interrupção do crédito, o que pode impedir os indivíduos de ter acesso a recursos indispensáveis.

Analisando as relações não significativas do modelo, foi possível identificar que se referem a atitude ao endividamento, atitude financeira, conhecimento financeiro, possuir cartão de crédito, empréstimo do nome, controle de gastos e menores níveis de renda. Podese induzir que esses representam posições específicas diante de situações e objetos, as quais dependem de como os indivíduos vão se comportar diante de situações, e como visto na teoria das finanças comportamentais, nem sempre as ações ocorrem de forma racional.

Como exemplo é possível elencar o fato dos indivíduos terem consciência que não deveriam se endividar, contudo, muitas vezes não conseguem manter a vida financeira em dia, seja por comprar em excesso ou sofrer restrições monetárias inesperadas. Outras 
situações se referem a possuir cartão de crédito e usá-lo de forma consciente ou não; emprestar o nome com garantias de pagamento ou apenas com confiança; possuir maior conhecimento financeiro e melhores atitudes financeiras, mas não apresentar um bom comportamento financeiro. Quanto a renda, se a administração dos recursos é efetiva, e as pessoas muitas vezes conseguem adequar a renda aos recursos e alcançar uma situação financeira favorável. Em suma, são situações sem efeito imediato na satisfação financeira, apesar de indiretamente poderem gerar algum desconforto.

Atendendo os objetivos específicos, observou--se que um alto percentual de respondentes possui dívidas, contudo a maioria não possui o nome ligado ao cadastro negativo, o que evidencia que a maioria deles estão conseguindo honrar com os compromissos em dia. Um fator preocupante, é que menos da metade possui poupança, os deixando mais vulneráveis a situações inesperadas que possam comprometer a renda e o consequente bem-estar financeiro. Outro fator relevante é o nível de conhecimento financeiro, que indicou que a maior parte dos indivíduos possui um baixo nível e menos de um quarto possuem bom conhecimento sobre finanças.

Quanto a validação dos construtos, após os procedimentos de ajuste adotados, confirmou-se a confiabilidade e validade convergente dos mesmos. Contatou-se que os indivíduos não possuem preocupações futuras com poupança e acabam realizando o consumo imediato do dinheiro. Identificou-se uma maior atenção dos respondentes a elaboração do plano de gastos e comparação de preços e o bem-estar financeiro se dá principalmente em função da satisfação financeira e do nível de dívidas. De maneira geral, a média dos construtos ratifica o baixo nível de atitude ao endividamento, atitude financeira e bem-estar financeiro.

Diante desses resultados, é possível afirmar que esse estudo contribui no avanço das pesquisas sobre bem-estar financeiro no Brasil, traçando um panorama do quão satisfeito os indivíduos estão com as suas finanças e o que influencia de forma mais significativa. Isso, torna-se muito importante no sentido de que foi possível assim, ser destacado quem necessita de maior contribuição para atingir um maior bem-estar financeiro, as quais são as pessoas com rendas mais baixas, com mau comportamento financeiro, que não praticam o ato de poupar, possuem o nome ligado ao cadastro negativo e conta bancária, o que se torna um alerta para a sociedade. Além disso, indivíduos satisfeitos financeiramente tendem a ser mais contentes com outros aspectos de sua vida. 
Destaca-se que as limitações do estudo estão diretamente relacionadas aos aspectos amostrais e de abordagem. Para trabalhos futuros, sugere-se a reaplicação do instrumento de pesquisa em diferentes amostras, inclusão de variáveis ambientais e culturais, além da avaliação se existem diferenças entre os gêneros, faixas de idade, e outras variáveis socioeconômicas e demográficas. Cabe ainda avançar no tema trazendo-se questões relativas aos motivos do alto percentual de dívidas e baixo nível de poupança, se em função de problemas macroeconômicos pelo qual o país vem passando, ou se por características pessoais, como materialismo, compras compulsivas e falta de organização financeira. 


\section{Referências}

Banco Central do Brasil (BCB). (2014). Pesquisa qualitativa sobre o processo de endividamento. Recuperado de https://www.bcb.gov.br/pec/appron/apres/Pesquisa_Endividamento.pdf

Beal, D. J., \& Delpachitra, S. B. (2003). Financial literacy among Australian university students. Economic Papers: A journal of applied economics and policy, 22(1), 65-78.

Brasil. Ministério do Desenvolvimento Social e Combate à Fome. Secretaria Nacional de Renda e Cidadania. Programa de Gestão do PBF. (2009). Recuperado de https://www.mds.gov.br/bolsafamilia/capacitacao/arquivos/apostilas/um-panoramada-gestao-do-bolsa-familia.pdf/view

Brown, S., \& Gray, D. (2016). Household Finances and Well-Being in Australia: An Empirical Analysis of Comparison Effects. Journal of Economic Psychology, 53, 17-36.

Chen, H., \& Volpe, R. P. (1998). An analysis of personal financial literacy among college students. Financial Services Review, 7(2), 107-128.

Cheung, G. W., \& Lau, R. S. (2008). Testing Mediation and Suppression Effects of Latent Variables Bootstrapping With Structural Equation Models. Organizational Research Methods, 11(2), 296-325.

Confederação Nacional do Comércio de Bens, Serviços e Turismo (CNC). (2016). Pesquisa Nacional de Endividamento e Inadimplência do Consumidor (PEIC) - abril 2016. Recuperado de http://www.cnc.org.br/sites/default/files/arquivos/analise_peic_abril_2016_o.pdf

Castro, K. G. M. C. (2014). O superendividamento do consumidor e seus reflexos na atividade empresarial. (Dissertação de Mestrado). Faculdade de Direito Milton Campos, Nova Lima, MG.

Consumer Financial Protection Bureau (CFPB). (2015). Financial well-being: The goal of financial education. Report, Iowa City, IA: Consumer Financial Protection Bureau. 
Costa Jr, N. C. A, Macedo Jr, J. S., Zindel, M. T. L., \& Arruda, P. B. (2007). Efeito disposição e experiência no mercado financeiro. Revista de Economia e Administração, 6(4), 447-463, out./dez.

Chen, I. J., Gu, Y., \& Chen, C. (2012). Family resource management style and life adjustment of low-income single mothers in China. Social Behavior and Personality, 4O(6), 959-970.

Delafrooz, N., \& Paim, L. H. (2011). Determinants of financial wellness among Malaysia workers. African Journal of Business Management, 5(24), 10092-10100.

Diniz, A. P. C., Vieira, K. M., Potrich, A. C. G., \& Campara, J. P. (2014). Influência das variáveis socioeconômicas e demográficas no bem-estar financeiro: um estudo do comportamento maranhense. Revista Uniabeu, 7(17), 218-234.

Falahati, L., Sabri, M. F., \& Paim, L. H. (2012). Assessment a model of financial satisfaction predictors: Examining the mediate effect of financial behaviour and financial strain. World Applied Sciences Journal, 2O(2), 190-197.

Gutter, M., \& Copur, Z. (2011). Financial behaviors and financial well-being of college students: Evidence from a national survey. Journal of Family and Economic Issues, 32(4), 699-714.

Hair, J. F., Black, W. C., Babin, B. J., \& Anderson, R. E. (2010). Multivariate Data Analyses.7 ed. New Jersey: Pearson.

Hooper, D., Coughlan, J., \& Mullen, M.R. (2008). Structural equation modelling: guidelines for determining model fit. The Electronic Journal of Business Research Methods, 6, 53-6o.

Instituto Brasileiro de Geografia e Estatística (IBGE). (2010). Estados, Censo Demográfico 201O. Recuperado de http://www.ibge.gov.br/estadosat/perfil.php?sigla=RS

Kahneman, D. (2003). A perspective on judgment and choice: mapping bounded rationality. American psychologist, 58(9), 697.

Kahneman, D., \& Tversky, A. (1979). Prospect theory: An analysis of decision under risk. Econometrica: Journal of the econometric society. 
Keese, M., \& Schmitz, H. (2011). Broke, ill, and obese: the effect of household debt on health. SOEP Papers, No. 35O. Recuperado de http://ssrn.com/abstract=1750216

Kim, J., Garman, E. T., \& Sorhaindo, B. (2003). Relationships among credit counseling clients' financial wellbeing, financial behaviors, financial stressor events, and health. Journal of Financial Counseling and Planning, 14(2), 75-87.

Klapper, L., Lusardi, A., \& Panos, G. A. (2013). Financial literacy and its consequences: Evidence from Russia during the financial crisis. Journal of Banking \& Finance, 37(10), 3904-3923.

Kline, R. B. (2011). Principles and practice of structural equation modeling 3 ed. New York: The Guilford Press.

Lown, J. M., \& Ju, I. S. (1992). A model of credit use and financial satisfaction. Financial Counseling and Planning, 3(1), 105-124.

Macedo Junior, J. Sell, Kolinsky, R., \& Morais, J. (2011). Finanças Comportamentais: Como o desejo, o poder, o dinheiro e as pessoas influenciam nossas decisões. Atlas.

Marques, M. M., \& Frade, C. (2004). Regular o sobreendividamento. Gabinete de Política Legislativa e Planeamento do Ministério da Justiça (Ed.), Código da Insolvência e da Recuperação de Empresas. Coimbra: Coimbra Editora.

Moura, A. (2005). Impacto dos Diferentes Níveis de Materialismo na Atitude ao Endividamento e no Nível de Dívida para Financiamento do Consumo nas Famílias de Baixa Renda do Município de São Paulo. (Dissertação de Mestrado). Fundação Getúlio Vargas, São Paulo.

Moreira, B. C. D. M. (2012). Três ensaios sobre finanças comportamentais e neuroeconomia: testando o efeito dotação, efeito overconfidence e efeito gratificação instantânea em crianças, (Tese de Doutorado). Universidade Federal de Santa Catarina, Florianópolis, SC, Brasil.

National Financial Capability Study (NFCS). (2012). Financial Capability in the United States. Report of Findings from the 2012 National Financial Capability Study. Financial Industry Regulatory Authority (FINRA) Investor Education Foundation. Recuperado de 
http://www.usfinancialcapability.org/downloads/NFCS_2012_State_by_State_Qre.pd f

National Foundation for Credit Counseling (NFCC). (2013). The 2013 Consumer Financial Literacy Survey - Report of The Network Branded Prepaid Card Association.

Recuperado de

http://www.nfcc.org/NewsRoom/FinancialLiteracy/files2013/NFC\%20C_NBPCA_201 3\%2oFinancialLiteracy_survey_datasheet_key\%2ofindings_o32913.pdf

Norvilitis, J. M., Szablicki, P. B., \& Wilson, S. D. (2003). Factors Influencing Levels of Credit-Card Debt in College Students. Journal of Applied Social Psychology, 33(5), 935947.

O'Neill, B., \& Xiao, J. J. (2012). Financial behaviors before and after the financial crisis: Evidence from an online survey. Journal of Financial Counseling and Planning, 23(1), $33-46$.

Organization for Economic Co-operation and Development (OECD). (2013a). PISA 2012 Assessment and Analytical Framework: Mathematics, Reading, Science, Problem Solving and Financial Literacy, OECD Publishing. Recuperado de http://dx.doi.org/10.1787/9789264190511-en

Organization for Economic Co-operation and Development (OECD). (2013b). Financial literacy and inclusion: Results of OECD/INFE survey across countries and by gender. OECD Publishing. Recuperado de http://www.oecd.org/daf/fin/financialeducation/TrustFund2013_OECD_INFE_Fin_Lit_and_Incl_SurveyResults_by_Count ry_and_Gender.pdf

Organisation for Economic Co-operation and Development International Network on Financial Education (OECD/INFE). (2015). National Strategies for Financial Education OECD/INFE Policy Handbook. Recuperado de http://www.oecd.org/daf/fin/financial-education/National-Strategies-FinancialEducation-Policy-Handbook.pdf

Porto, A. J. M. (2012). Over-Indebtedness in Brazil: Do We Need More Regulation?. Available at SSRN 2126713. 
Plagnol, A. C. (2011). Financial satisfaction over the life course: The influence of assets and liabilities. Journal of Economic Psychology, 32(1), 45-64.

Prawitz, A. D., Garman, E. T., Sorhaindo, B., O'Neill, B., Kim, J., \& Drentea, P. (2006). InCharge financial distress/financial well-being scale: Development, administration, and score interpretation. Journal of Financial Counseling and Planning, 17(1).

Van Rooij, M. C., Lusardi, A., \& Alessie, R. J. (2011). Financial literacy and retirement planning in the Netherlands. Journal of Economic Psychology, 32(4), 593-6o8.

Shefrin, H., \& Statman, M. (1994). Behavioral capital asset pricing theory. Journal of financial and quantitative analysis, 29(03), 323-349.

Shim, S., Xiao, J. J., Barber, B. L., \& Lyons, A. C. (2009). Pathways to life success: A conceptual model of financial well-being for young adults. Journal of Applied Developmental Psychology, 30(6), 708-723.

Shockey, S. S. (2002). Low-wealth Adults' Financial Literacy, Money Management Behaviors, and Associated Factors, Including Critical Thinking. (Doctoral dissertation). Ohio State University, Utah.

Serviço de Proteção Ao Crédito (SPC). (2016). Análise da educação financeira: dívidas. Recuperado de https://www.spcbrasil.org.br/uploads/st_imprensa/analise_educacao_financeira_divi das2.pdf

Sumarwan, U. (1990). A Managerial System Approach To Factors Influencing Satisfaction With Households' Financial Status (Doctoral dissertation). Iowa State University, Ames.

Vlaev, I., \& Elliott, A. (2014). Financial Well-Being Components. Social Indicators Research, 118(3), 1103-1123.

Xiao, J. J., Sorhaindo, B., \& Garman, E. T. (2006). Financial behaviours of consumers in credit counselling. International Journal of Consumer Studies, 3o(2), 108-121.

White, H. (1980). A heteroskedasticity-consistent covariance matrix estimator and a direct test for heteroskedasticity. Econometrica: Journal of the Econometric Society, 817-838. 
Submissão: 04/05/2016

Segunda versão: 12/o8/2016

Aceite: 21/o8/2016 
Apêndice

Estatística Descritiva dos Construtos

\begin{tabular}{|c|c|c|c|}
\hline Construto & Questão & Variável & Média \\
\hline \multirow{8}{*}{ 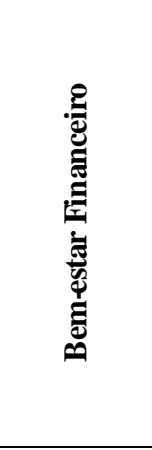 } & BE1 & Você se sente financeiramente satisfeito. & 2,83 \\
\hline & BE2 & Você acredita estar em uma boa situação financeira. & 2,85 \\
\hline & BE3 & Daqui a 1 ano, você pretende ter pago todas as suas dívidas. & 3,81 \\
\hline & BE4 & Daqui a 5 anos, você pretende ter pago todas as suas dívidas. & 3,96 \\
\hline & BE5 & Você se sente desconfortável com a quantia que deve.* & 3,06 \\
\hline & BE6 & Você se preocupa constantemente com o pagamento de suas dívidas.* & 3,92 \\
\hline & BE7 & Você pensa muito em suas dívidas.* & 3,49 \\
\hline & BE8 & $\begin{array}{l}\text { Você tem tido discussões com outras pessoas (pais, amigos, esposo(a) e } \\
\text { outros) devido à sua dívida.* }\end{array}$ & 2,26 \\
\hline \multirow{10}{*}{ 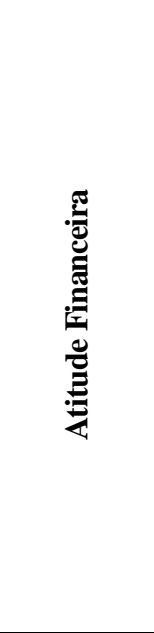 } & AF1 & Para você, é importante definir metas para o futuro.* & 4,47 \\
\hline & $\mathrm{AF} 2$ & $\begin{array}{l}\text { Você acredita que a maneira como administra seu dinheiro vai afetar o } \\
\text { seu futuro.* }\end{array}$ & 3,87 \\
\hline & AF3 & Você não se preocupa com o futuro, vive apenas o presente. & 1,93 \\
\hline & $\mathrm{AF} 4$ & Poupar é impossível para a sua família. & 2,32 \\
\hline & AF5 & $\begin{array}{l}\text { Depois de tomar uma decisão sobre dinheiro, você se preocupa muito } \\
\text { com a sua decisão. }\end{array}$ & 3,37 \\
\hline & AF6 & Você gosta de comprar coisas, porque isso faz você se sentir bem. & 3,05 \\
\hline & AF7 & É difícil construir um planejamento de gastos familiar. & 2,82 \\
\hline & AF8 & $\begin{array}{l}\text { Você se permite gastar dinheiro em coisas que são importantes para } \\
\text { você. }\end{array}$ & 3,71 \\
\hline & AF9 & $\begin{array}{l}\text { Você considera mais satisfatório gastar dinheiro do que poupar para o } \\
\text { futuro. }\end{array}$ & 2,39 \\
\hline & $\mathrm{AF} 10$ & Para você, o dinheiro foi feito para gastar. & 2,85 \\
\hline \multirow{9}{*}{ 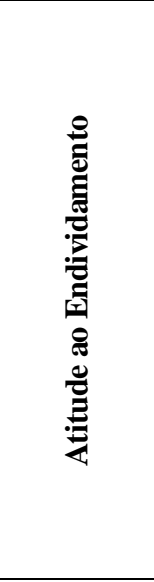 } & AE1 & $\begin{array}{l}\text { Para você, é normal as pessoas ficarem endividadas para pagar suas } \\
\text { contas. }\end{array}$ & 2,26 \\
\hline & AE2 & $\begin{array}{l}\text { Você prefere comprar parcelado do que esperar ter dinheiro para } \\
\text { comprar à vista. }\end{array}$ & 2,62 \\
\hline & AE3 & Você prefere pagar parcelado mesmo que no total saia mais caro. & 2,17 \\
\hline & AE4 & Não tem problema ter dívida se você sabe que pode pagar. & 3,23 \\
\hline & AE5 & Não é certo gastar mais do que você ganha.* & 4,23 \\
\hline & AE6 & $\begin{array}{l}\text { As pessoas ficariam desapontadas contigo se soubessem que você tem } \\
\text { dívidas.* }\end{array}$ & 2,68 \\
\hline & AE7 & É melhor primeiro juntar dinheiro e só depois gastar.* & 3,72 \\
\hline & AE8 & $\begin{array}{l}\text { Você sabe exatamente quanto deve em lojas, cartão de crédito ou } \\
\text { banco.* }\end{array}$ & 3,97 \\
\hline & AE9 & É importante saber controlar os gastos da sua casa.* & 4,41 \\
\hline \multirow{8}{*}{ 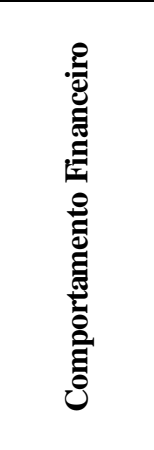 } & CF1 & Você anota e controla os seus gastos (Ex.: com planilha). & 3,24 \\
\hline & $\mathrm{CF} 2$ & Você compara preços ao fazer uma compra. & 3,94 \\
\hline & CF3 & Você tem um plano de gastos/ orçamento. & 3,29 \\
\hline & CF4 & $\begin{array}{l}\text { Você consegue identificar os custos que paga ao comprar um produto } \\
\text { no crédito. }\end{array}$ & 3,69 \\
\hline & CF5 & Você paga as suas contas em dia. & 4,44 \\
\hline & CF6 & Você analisa suas contas antes de fazer uma compra grande. & 4,57 \\
\hline & $\mathrm{CF} 7$ & Você passa a poupar mais quando recebe um aumento de salário. & 3,35 \\
\hline & CF8 & Nos últimos 12 meses, você tem conseguido poupar dinheiro. & 2,86 \\
\hline
\end{tabular}

*Variável invertida. 